\title{
Sperm quality and testicular morphometry of rabbits fed dietary levels of water spinach (Ipomoea aquatica) leaf meal
}

\author{
T. Ahemen ${ }^{1}$, A.H Abu $^{2 *}$ and T.T. Orakaanya ${ }^{1}$ \\ ${ }^{1}$ Department of Animal Breeding and Physiology, University of Agriculture, PMB 2373, \\ Makurdi, ${ }^{2}$ Department of Veterinary Physiology, Pharmacology and Biochemistry, University \\ of Agriculture, PMB 2373, Makurdi, Benue state, Nigeria \\ *Author' address for correspondence: adakoleabu@yahoo.co.uk; Telephone: \\ $+234(0) 8060396898$

\begin{abstract}
A total of twenty four rabbits of mixed breeds aged 10 - 12 weeks and weighed between $900-$ $1000 \mathrm{~g}$, were used in an experiment to determine the effect of feeding varying dietary levels of water spinach (Ipomoea aquatica) leaf meal on reproductive parameters and organ weights of male rabbits. The rabbits were randomly allocated into four dietary treatments, $T_{1}, T_{2} T_{3}$ and $T_{4}$ containing $0 \%, 5 \%, 10 \%$ and $15 \%$ of water spinach leaf meal respectively. Feed and water were served ad libitum throughout the 8 weeks experimental period. At the end of the feeding trial, 3 rabbits per treatment were slaughtered and their reproductive organs were carefully dissected out and separated into different components. The testicular morphometry and cauda epididymal sperm characteristics were evaluated. The result showed no significant $(P>0.05)$ effect of diet on testicular morphometry and sperm characteristics. No significant $(P>0.05)$ effect of diet was also observed on the internal organ weights of the male rabbits. This result shows that water spinach meal can be included up to $15 \%$ in rabbit diets without adverse effect on testicular morphometry and sperm quality of male rabbits.
\end{abstract}

Keywords: Rabbits, sperm, testicular morphometry, water spinach leaf meal,

\section{INTRODUCTION}

In most developing countries including Nigeria, the supply of qualitative animal protein in sufficient quantity and at affordable cost has continued to remain a major challenge to the livestock industry. Rabbit as micro-livestock is an economic animal that could bridge the wide gap in dietary protein in the country. This is because rabbit is socially acceptable on the combined basis of space requirement and absence of religious taboos as well as peculiar digestive physiology which permits the use of forages and agro-industrial by products, thus making it non competitive specie with man for cereals and legume grains. The exploitation of plants of low economic importance would be a step towards better resource utilization (Telek, 1983) which is in line with the strategy to achieve sustainable animal production systems by matching them with locally available feed resources (Preston and Sansoucy, 1987).

Water spinach is an herbaceous trailing vine that dwells in muddy stream bank, fresh water ponds and marshes. This perennial aquatic vine is confined to the tropics and sub tropics because it is well adapted to forest region and does not grow well when temperature is below $24^{\circ} \mathrm{C}$. Water spinach can reproduce sexually by producing one to four seeds in fruiting capsules or vegetative by stem fragmentation (Prasad et al., 2008). It is widely consumed vegetable in South east Asia. Although it is widespread in Africa, the herbs are eaten mostly in Ethiopia, Sudan and Tanzania (Dalziel, 1937, Vaino- Mattila, 2000). There are records of Ipomea aquatica being used to treat diabetes (Iwu,1993), Abscesses and intestinal disorders (Samuelsson et al. 1992) Some studies have shown antidepressant and antiepileptic ( Sivaraman and Muralidaran, 2010) activities of Ipomea aquatica. The effect of water spinach on the growth performance and carcass yield of rabbit has been reported (Chat et al., 2005). However, there is lack of wealth of information on the effect of water spinach on rabbit's reproduction. This study was therefore designed to evaluate the effect of feeding varying levels of water spinach on cauda epididymal sperm characteristics and testicular morphometry of male rabbits. 


\section{MATERIALS AND METHODS}

Location-The study was conducted at the Rabbitry unit of the livestock Research Farm, University of Agriculture Makurdi. Makurdi is located at Latitude $7^{\circ} 14^{\prime}$ North and Longitude $8^{\circ} 24^{\prime}$ East and lies within the Southern Guinea Savannah Region of Nigeria. The annual temperature ranges from 22.43 to $33.41^{\circ} \mathrm{C}$. High temperature is experienced between late February and April. The annual rainfall is between 1270mm-1397mm (Abu, 2002).
Test ingredients-Water spinach plants were collected around river Benue banks in Makurdi. The plants were sun dried, powdered and included at the levels of $0,5,10$, and $15 \%$ in the diets labeled $T_{1}, T_{2}$, $\mathrm{T}_{3}$ and $\mathrm{T}_{4}$ respectively (Table 1 ). Other ingredients used include: - soybeans, maize offal, maize, rice offal, premix, bone meal and salt. The diets were formulated to meet $16 \%$ crude protein requirement for growing rabbits.

Table 1: Gross composition of experimental diet

\begin{tabular}{|c|c|c|c|c|}
\hline \multirow[b]{2}{*}{ Ingredients } & \multicolumn{4}{|c|}{ Diets } \\
\hline & $\overline{\mathrm{T}_{1}}$ & $\mathrm{~T}_{2}$ & $\mathrm{~T}_{3}$ & $\mathrm{~T}_{4}$ \\
\hline Maize & 29.95 & 29.95 & 29.00 & 30.95 \\
\hline Full fat soya bean & 28.00 & 27.50 & 26.55 & 26.00 \\
\hline Maize Bran & 24.00 & 19.50 & 15.00 & 15.00 \\
\hline Rice offal & 15.00 & 15.00 & 15.00 & 15.00 \\
\hline Water spinach & 0.00 & 5.00 & 10.00 & 15.00 \\
\hline Premix & 0.25 & 0.25 & 0.25 & 0.25 \\
\hline Salt & 0.3 & 0.3 & 0.3 & 0.3 \\
\hline Total & 100.00 & 100.00 & 100.00 & 100.00 \\
\hline \multicolumn{5}{|c|}{ Calculated values (\%) } \\
\hline Crude protein & 18.28 & 18.28 & 18.28 & 18.04 \\
\hline Crude fibre & 9.01 & 9.46 & 9.79 & 10.14 \\
\hline Dry Matter & 93.40 & 93.45 & 93.51 & 93.77 \\
\hline Calcium & 0.55 & 0.54 & 0.54 & 0.53 \\
\hline Phosphorus & 0.65 & 0.63 & 0.62 & 0.60 \\
\hline \multicolumn{5}{|c|}{$\begin{array}{l}T_{1}=0 \% \text { water spinach meal } \\
T_{3}=10 \% \text { water spinach meal }\end{array}$} \\
\hline
\end{tabular}

Experimental animals and management- $A$ total of twenty four weaned rabbits of mixed breeds, aged between 10 and 12 weeks with average weight of $995.75 \mathrm{~g}$ were used for the study. The rabbits were randomly assigned to the four (4) treatments with six (6) rabbits per treatment. Each rabbit served as replicate. The rabbits were weighed individually at the beginning of the study and weekly thereafter. The experimental animals were sacrificed at the end of the feeding trial that lasted for eight weeks.

Reproductive indices-The scrotal sacs were incised to exterionize the testes. The epididymides were separated from the testes and other adhering tissues. The testes were weighed and their volumes were determined by water displacement. The lengths and widths of the testes were measured using a thread and metre ruler. The cauda epididymides were then excised from the epididymides and several lacerations were made on them as they were individually placed in separate beakers containing 5 $\mathrm{ml}$ Physiological saline solution into which spermatozoa were liberated. Sperm concentrations were determined using the improved Neubauer haemocytometer. Sperms' progressive motility, percentage live spermatozoa and morphology of spermatozoa were determined by conventional methods (Zemjanis, 1977).

Data analysis-Data obtained were subjected to analyses of variance and correlation using GenStat (Release 4.24) statistical package (Genstat, 2005). Significant differences between treatment means were separated using Duncan's Multiple Range Test (Steel and Torrie, 1980).

\section{RESULTS AND DISCUSSION}

The results of testicular morphometry of rabbits fed water spinach meal are presented in Table 2. The 
knowledge of basic morphometric characteristics of the reproductive tract have been found to provide valuable information in the evaluation of breeding and fertility potential of the animals (Ogbuewu et al. 2009). Gage and Freckleton (2003) described the mammalian testes as infallible predictors of spermatozoa production. The authors further asserted that knowledge of the basic morphometric characteristics of the reproductive organs is mandatory for assessment and prediction not only of sperm production but also of the storage potential and fertilizing ability of the breeder male. The paired testes weight in this study were not significantly ( $p>0.05$ ) influenced by dietary treatments. The result is similar to the report of Bitto and Gemade (2001) who observed non significant effect of pawpaw peel meal (PPM) up to $30 \%$ on testicular morphometry of male rabbits. The finding also agrees with the report of Ogunlade et al. (2006) who observed non significant differences in testis weight among rabbits fed fumonisin contaminated diets. The finding, Table 2.Testicular morphometry of rabbit bucks fed water spinach meal however, contrasts with the reports of Bitto et al. (2000) who observed a significant decrease in paired testes weight of cockerels fed cassava peel meal up to $30 \%$ in diet. Egbunike (1979) observed testicular degeneration and impaired spermatogenesis in rats treated with sub lethal doses of aflatoxin. The mean testicular length and width values ranged from $2.43 \pm 0.007$ to $2.65 \pm 0.15 \mathrm{~cm}$ and $0.98 \pm 0.0$ to $1.07 \pm 0.07 \mathrm{~cm}$ respectively. The values of testicular length and width obtained in this study are similar to ranges of 2.26 to $4.40 \mathrm{~cm}$ and 0.94 to $1.10 \mathrm{~cm}$ for testicular length and width respectively reported by Ajayi et al. (2009) in rabbits. The values were not significantly ( $p>0.05)$ influenced by diets. Ajayi et al. (2009) however, observed significant effect of diets (Blood-wild sunflower leaf meal mixture diet) on testicular length of rabbits. According to Ezekwe (1998) and Perry and Petterson (2001), testes size, length and width are good indicators of present and future sperm production.

\begin{tabular}{|l|c|c|c|c|c|}
\hline \multicolumn{5}{|c|}{ Experimental Diets } \\
\hline Parameters & $\mathrm{T}_{1}$ & $\mathrm{~T}_{2}$ & $\mathrm{~T}_{3}$ & $\mathrm{~T}_{4}$ & LOS \\
\hline $\begin{array}{l}\text { Paired testis weight } \\
(\mathrm{g})\end{array}$ & $2.58 \pm 0.42$ & $2.92 \pm 0.73$ & $3.23 \pm 0.19$ & $2.98 \pm 0.10$ & $\mathrm{~ns}$ \\
\hline Testis length (cm) & $2.56 \pm 0.11$ & $2.43 \pm 0.07$ & $2.80 \pm 0.25$ & $2.65 \pm 0.15$ & $\mathrm{~ns}$ \\
\hline $\begin{array}{l}\text { Testis } \\
\text { width }(\mathrm{g})\end{array}$ & $1.07 \pm 0.07$ & $1.03 \pm 0.04$ & $1.08 \pm 0.02$ & $0.98 \pm 0.01$ & $\mathrm{~ns}$ \\
\hline $\begin{array}{l}\text { Testis } \\
\text { volume }\left(\mathrm{cm}^{3}\right)\end{array}$ & $2.32 \pm 0.30$ & $1.95 \pm 0.05$ & $2.00 \pm 0.08$ & $1.92 \pm 0.04$ & $\mathrm{~ns}$ \\
\hline
\end{tabular}

$\mathrm{T}_{1}=0 \%$ water spinach meal $\mathrm{T}_{2}=5 \%$ water spinach meal $\quad$ Los=Level of significance

$\mathrm{T}_{3}=10 \%$ water spinach meal $\quad \mathrm{T}_{4}=15 \%$ water spinach meal $\quad \mathrm{ns}=$ not significant $5 \%(P>0.05)$

The results of the sperm characteristics of rabbits fed water spinach leaf meal are presented in Table 3. It is well established that motility develops gradually from caput to cauda epididymis and more mature and motile spermatozoa capable of fertilization are found in the cauda epididymis (Hafez, 1987). Ajayi et al. (2009) established the effect of nutrition on sperm characteristics of rabbits. No significant effect of diet was observed on sperm motility in this study. Values obtained ranged from $65.00 \pm 1.20$ to $68.30 \pm 1.22 \%$ and were lower than the range of 67.00 to $77.00 \%$ reported by Ajayi et al. (2009) in the cauda epididymis of rabbits fed graded levels of blood-wild sunflower leaf meal mixture diet. Oyeyemi et al. (1998) stated that adequate nutrition with high percentage of protein will enhance motility and concentration of spermatozoa. Oyeyemi and Okendran (2007) fed varying levels of soy meal to rabbits and reported that motility of spermatozoa increased as the percentage of soy meal levels was increased in diet. The workers attributed the increase in motility to the high level of protein and fat in the soy meal. The non significant influence of diet on motility is an indication that the test diet has supply of adequate protein to support optimum sperm motility. Evans and Maxwell (1987) reported that a characteristic feature and prerequisite for the fertilizing capacity of spermatozoa is their motility.

The sperm concentration values obtained in this study range from $123.30 \pm 1.76$ to $128.30 \pm 1.20$ $\mathrm{x} 10^{6} / \mathrm{ml}$ and were comparable to the range of 126.00 
to $154.00 \times 10^{6} / \mathrm{ml}$ reported by Ajayi (2009). Oyeyemi and Okendran ( 2007) stated that high concentration of spermatozoa is an indication of possible high fertility rate by the reason of the number of spermatozoa available at the time of copulation or insemination. The percentage live sperm cells in this study range from $78.60 \pm 1.20$ to $84.00 \pm 2.08 \%$ and were not significantly influenced by dietary treatments. Arthur et al. (1989) reported that good semen samples show an average of $25 \%$ dead sperms. Therefore, the mean value of percentage live sperm cells obtained in this study was within the range of good samples. The percentage live sperm cells are available for fertilization (Ajala et al. 2001). The percentage abnormal sperm cells values in this study range from $9.60 \pm 0.88$ to $10.90 \pm 0.78$. The values were within the range of 6.00 to $16.00 \%$ reported by Ajayi (2009). The percentage of abnormal sperm cells in this study were below the upper limit of $20 \%$ recommended as the minimum for good reproductive potential and fertility in either normal mating or in artificial insemination (Oyeyemi and Okediran, 2007).

Table 3.Sperm characteristics of rabbit bucks fed water spinach meal

\begin{tabular}{|c|c|c|c|c|c|}
\hline \multicolumn{6}{|c|}{ Experimental Diets } \\
\hline Parameters & $\mathrm{T}_{1}$ & $\mathrm{~T}_{2}$ & $T_{3}$ & $\mathrm{~T}_{4}$ & LOS \\
\hline Sperm motility (\%) & $68.00 \pm 1.16$ & $65.00 \pm 1.20$ & $68.30 \pm 1.22$ & $66.00 \pm 1.06$ & ns \\
\hline $\begin{array}{l}\text { Sperm } \\
\text { concentration }\left(\times 10^{6}\right)\end{array}$ & $123.30 \pm 1.76$ & $128.00 \pm 1.16$ & $138.30 \pm 1.20$ & $127.30 \pm 1.50$ & ns \\
\hline Live sperm (\%) & $84.00 \pm 2.08$ & $79.67 \pm 1.20$ & $79.60 \pm 1.45$ & $78.60 \pm 1.20$ & ns \\
\hline Abnormal sperms (\%) & $9.60 \pm 0.88$ & $10.30 \pm 0.80$ & $10.90 \pm 0.78$ & $9.80 \pm 1.00$ & ns \\
\hline
\end{tabular}

$\mathrm{T}_{1}=0 \%$ water spinach meal $\mathrm{T}_{2}=5 \%$ water spinach meal $\quad$ Los=Level of significance

$\mathrm{T}_{3}=10 \%$ water spinach meal $\quad \mathrm{T}_{4}=15 \%$ water spinach meal $\quad \mathrm{ns}=$ not significant $5 \%(P>0.05)$

The result of the visceral organ weights of male rabbits fed water spinach is presented in Table 4. There was no significant ( $p>0.05)$ effect of diet on all the parameters studied. The values did not follow specific pattern. The result of the study is similar to the report of Torhemen (2008) who observed non significant effect of CPM on organ weights of male rabbits. This means that feeding water spinach leaf meal poses no serious consequence on organs functions and developments

The results of this study showed that water spinach meal up to $15 \%$ inclusion supported normal reproductive tract development, sperm quality and visceral organ weights of rabbit bucks.

Table 4: Visceral organ weights $(\mathrm{g})$ of rabbit bucks fed water spinach meal

\begin{tabular}{|c|c|c|c|c|c|c|}
\hline diets & & & & & & \\
\hline Parameters & $\mathrm{T}_{1}$ & $\mathrm{~T}_{2}$ & $\mathrm{~T}_{3}$ & $T_{4}$ & SEM & los \\
\hline Average final & & & & & & \\
\hline Weight gain & 1483 & 1600 & 1476 & 1533 & 152.8 & ns \\
\hline Liver & 47.84 & 46.04 & 43.42 & 43.40 & 7.78 & ns \\
\hline Lungs & 10.86 & 11.66 & 10.88 & 9.44 & 2.80 & ns \\
\hline Heart & 3.30 & 3.54 & 3.98 & 3.71 & 0.62 & ns \\
\hline Spleen & 0.56 & 0.51 & 0.54 & 0.59 & 0.07 & ns \\
\hline Kidney & 11.17 & 10.47 & 10.01 & 8.75 & 1.72 & ns \\
\hline SEM & idard E & of the Mean & $\mathrm{LOS}=\mathrm{L} \epsilon$ & gnificanc & ot signifi & t $5 \%(P>0.05)$ \\
\hline
\end{tabular}



$26 \mathrm{~S}$

University of Agriculture Makurdi-Nigeria pp 22-

Ajala, O.O., Oyeyemi, M.O., Akusu, M. O. and Eimunjeze, H.E. (2001). The effects of scrotal insulation on the testicles and spermatozoa characteristics of WAD goats. Sokoto J. Vet. Sc. 3 (1) 44-50.

Ajayi, A.F., Raji, Y. and Togun, V. (2009) Caudal epididymal sperm characteristics nd testicular morphometrics of rabbits fed graded levels of a blood-wild sunflower leaf meal (BWSLM) mixture diet . J. Compl. Integr.. Med. V. (6) 1,26

Arthur, G.H. Noakes D.E and Pearson, H. (1975). Veterinary reproduction and obstetrics. Baillere Tindal, London, pp 509-589.

Bitto, I.I., Sende, C.T. and Eze, P.U. (2000). Preliminary investigations on to the effect of cassava peel meal on testicular morphometry and some biochemical characteristics of serum in cockerels. Global J. Pure and Appl. Sci. 6(2). 161-165.

Bitto, I.I. and Gemade, M. (2001).Preliminary investigations on the effect of Pawpaw peel meal on growth, visceral organ and endocrine gland weights, testicular morphometry and the haematology of male rabbits, Global J.P. \& Appl. Sci. 7(4); $611-625$.

Chat, T.H. Dung, N.T. Binh, D. V. and Preston T.R. (2005). Water spinach (Ipomoea aquatica) as a replacement for guinea grass for growing and lactating rabbits. Goat and Rabbits. Research Centre, Sontay, Hatay, Vietnam. Livestock Research for Rural development.17 (10) www.Irrd.org//rrd17/10/chat17109

Dalziel, J.M. 1937. The Useful Plants of West Tropical Africa. Crown Agents for Oversea Governments and Administrations, London.

Dressler, K. (1995). Water spinach (Ipomoea aquatica) exotic aquatics on the move. University of Florida, center for Aquatic and invasive Plants.

Egbunike,G.N. (1979). The effects of micro doses of aflatoxin $B_{1}$ on sperm production rates epididymal sperm abnormality and fertility in the rat. Zbl. Vet. Med.,26: 66-72.

Evans, G. and Maxwell, W.M.C. (1987). Salmon's Artificial insemination of sheep and goats. Butterworth's Sydney pp 85-106

Ezekwe, A.G. (1998). Gonadal and extragonadal sperm reserve and testicular histometry of post pubertal Muturu bulls. Nig. J. Anim. Prod., 25: 106-110.

Gage, M.J.G. and Freckleton, R.P. (2003). Relative testis size and sperm morphometry across mammals: No evidence for an association between sperm competition and sperm length. Proceedings of Biological Science. 22:625-632.
GenStat (2005). GenStat user's Guide (Release 4.24). Lawes Agricultural Trust, Rothamsted Experimental station,UK.

Hafez, E.S.S. (1987). Advances in reproduction biology semen's evaluations In: Reproduction in farm animals. $5^{\text {th }}$ ed.

Iwu, M.M. 1993. Handbook of African Medicinal Plants. CRC Press. Boca Raton, FL.

Ogbuewu, I.P., Okoli, I.C. and Iloeje, M. (2009). Semen quality characteristics, reaction time, testis weight and seminiferous tubule diameter of buck rabbits fed neem (Azadiractita indica A juss) leaf meal based diet. Iranian Journal of Reproductive Medicine 7 (1) 23-28

Ogunlade, J.T., Ewuola, E.O. and Gbore, F.A. (2006). Testicular and epididymal sperm researves of rabbits fed fumonisin contaminated diets. Int. Digital Organisation for Scientific Information. 1(1) : 35-38

Oyeyemi, M. O., Ajala, O.O, Akusu, M.O and Agbesola, O.O. (1998). Effects of starvation on semen characteristics of WAD bucks. Proc. 1st Ann. Conf. ASAN. Sept. 22-24, Lagos, Nigeria Pp 128-130.

Oyeyemi, M.O. and Okediran, B.S. (2007). Testicular parameters and sperm morphology of chinchilla rabbits fed with different planes of soy meal. Int.J.Morphol.,25 (1):139-144.

Perry G, Petterson D. Determining reproductive fertility in herd bulls. University of Missouri Agriculture publication 2001; 2011:1-8.

Preston, T.R. and Sansoucy, R. (1987). Matching livestock system with available feed resources. In; proceeding of the FAO expert consultation on the substitution of imported concentrate feeds in animal production system in developing countries. FAO Animal Production and Health Paper no. 63: 32-41.

Samuelsson, G., M.H. Farah, P. Claeson, M. Hagos, M.Thulin, O. Hedberg, A.M. Warfa, A.O. Hassan, A.H. Elmi, A.D. Abdurrahman, A.S. Elmi, Y.A. Abdi \& H.H. Alin. 1992. Inventory of plants used in traditional medicine in Somalia II. Plants of the families Combretaceae to Labiatae. Journal of Ethnopharmacology 37:47-70.

Sivaraman D. and Muralidaran P. (2010). CNS Depressant and Antiepileptic Activities of the Methanol Extract of the Leaves of Ipomoea Aquatica Forsk. E-Journal of Chemistry 7(4):

Steel, R.G.D. and Torrie, J.H. (1980). Principles and procedures of statistics. A biometrical Approach. $2^{\text {nd }}$ Edn. Mc Graw-hill Book co. Inc. New York.

Telek, L and martin, F.W. (1983). Tropical Plants for leaf protein concentrate. In : leaf protein concentrate 
Agric. Biol. J. N. Am., 2013, 4(3): 352-357

(Editors: L. Telek and H.D. Graham). Av 1 Pub. U.S.A. PP 81-116.

Torhemen, M. (2008). The effect of cassava peel meal on performance, blood chemistry and reproductive potentials of male rabbits. M.Sc. Thesis Department of Animal Prodiuction ,University of Agriculture Makurdi, P 40-42.
Vaino-Mattila, K. 2000. Wild vegetables used by the Sambaa in the Usambara Mountains, NE Tanzania. Annales Botanici Fennici 37:57-67.

Zemjanis R. Collection and evaluation of semen. In: Diagnostic and therapeutic techniques in animal reproduction. The Williams and Wilkins Co. Baltimore, 1977; 242 pp. 